\title{
Our resilience needs to take root and blossom
}

Written by: Noriaki Abe, Counsellor, Permanent Delegation of Japan to the OECD

Last update: 25 February 2020

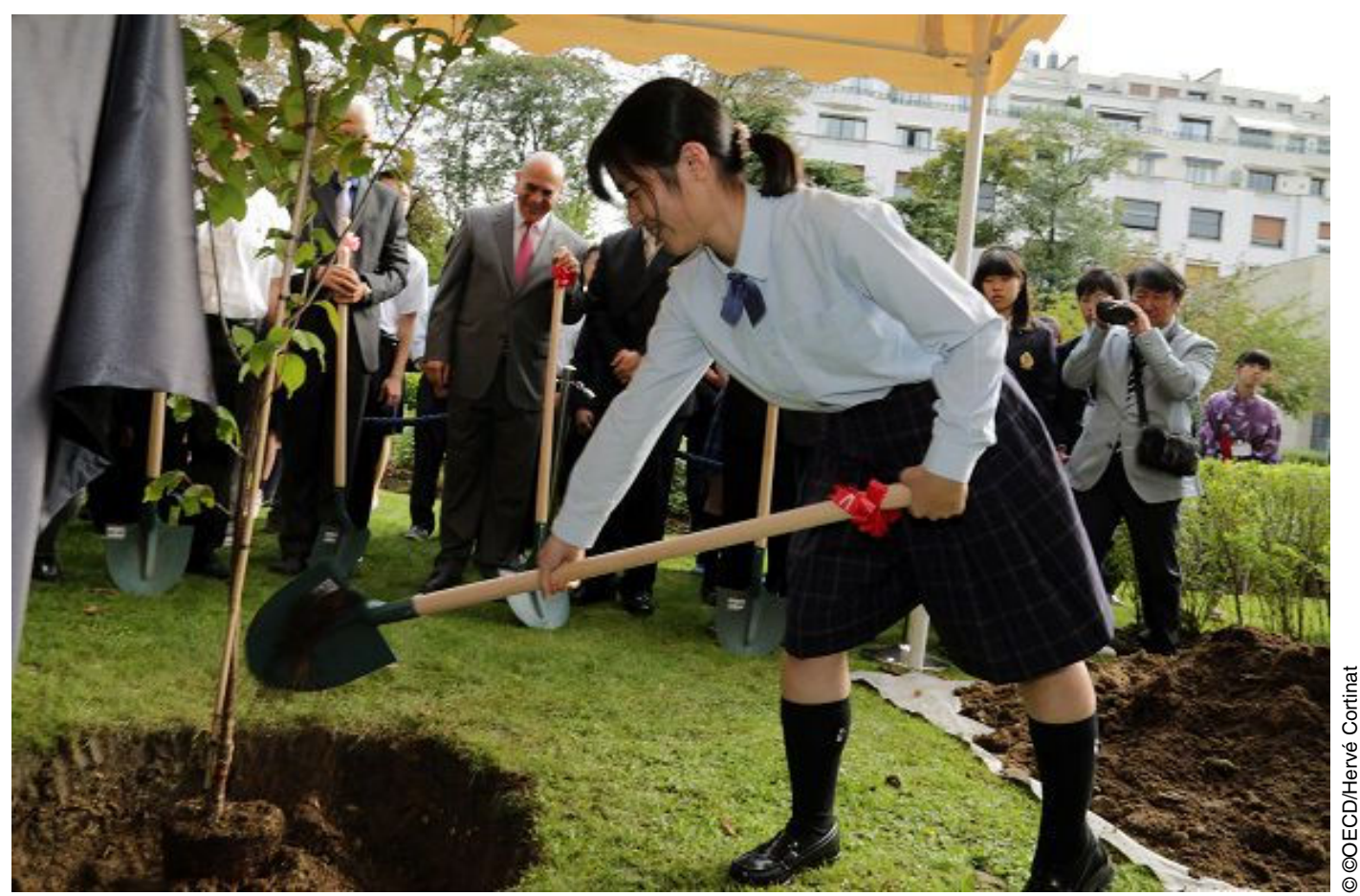

Our resilience needs to take root and blossom I Rina Matsumoto, Student Sakura team leader from Fukushima, plants a cherry tree at the OECD HQ for the Tohoku Cherry Blossom Ceremony, 2/9/14.

In the garden of the OECD headquarters in Paris, a cherry tree was planted in the autumn of 2014 by a group of Japanese high school students, who had suffered the earthquake in Fukushima in March 2011.

They were inspired by the beauty and vitality of the blossoms, which barely survived the devastating tsunami that the earthquake triggered and which killed many thousands of people. So when finishing an OECD summer programme, the students chose a young cherry tree to symbolise their appreciation of the OECD and commemorate their enduring partnership. Since then, the cherry tree has never failed to bloom in spring, reminding us of the resilience that has always been Japan's hallmark. 
Beyond the context of disaster reduction and preparedness, there is another "national resilience", or "Kokudo-kyojin-ka" in Japanese, which Prime Minister Shinzo Abe promotes.

Resilience is a term that is widely used by policymakers in domains such as economy, finance, employment and urban planning, as well as national security. Resilience is like a bamboo tree, which shows endurance and flexibility while bending against violent winds, and bouncing back even stronger.

But surely, true resilience means more than that, and using a cherry tree as a symbol of resilience, with its fragile beauty and symphony of flowers in the springtime, gives food for thought. After all, it is not just about standing firm, but rejuvenation and going on to building better lives, too.

Normally, resilience, for pragmatic purposes, aims at avoiding potential dangers and addressing crises such as the co-ordinated efforts of countries to avoid a financial meltdown after 2008. It must also address any fragility in existing systems and institutional capabilities. For example, resilience not only suggests that policymakers build higher and more robust walls against flooding, but also design emergency plans for providing electricity and transport resources in efficient and responsive ways. It also demands leadership by looking forward to the aftermath, planning for tomorrow, and anticipating the fallout and impact among different communities and individuals. Indeed, in the framework of resilience, anticipation plays a critical role.

However, it is also important to recognise the limitations of foresight, to remain responsive and sensitive. The mere realisation of the limits of anticipation is already a bold departure from the conventional methods of "risk-management" or "situation-control", where too much reliance is placed on well-laid plans. Dealing with unpredictability is also a quality of resilience. In our era of globalisation and digitalisation, new threats are emerging, rampant and potentially catastrophic in the public and private sectors alike, and blind to national borders. The usefulness of "thinking of the unthinkable" cannot be underestimated, or thought of as a game. Yet such inclusive and pragmatic approaches to resilience have been few and far between even in the international arena.

Could the OECD help to promote this holistic view? Given its rather bruising experience of the 2008 crisis and its push for new approaches to economic challenges, it would seem an excellent fit. The organisation's interdisciplinary prowess, ability to analyse complexities using evidence-based methods, and drive to integrate different policy domains holistically, all augur well for a new, fresher approach to resilience. The world's largest think tank, as our Prime Minister characterised the OECD, already divides the systemic cycle of resilience into four action phases: first, prepare/plan; second, absorb; third, restore; and fourth, adjust (see references). Its reviews and case studies lead to principles, guidelines and recommendations for policymakers from diverse countries and interests. 
Recently, the abysmal consequences of both natural and man-made disasters testify to the vulnerability of our people and our institutions to invisible threats and unexpected events, making it hard to sustain even a decent level of functionality and services at such times. Resilience, in its more applicable and practical form, would help us strengthen the architecture of our economic and social systems, empower people in local communities, consolidate infrastructure planning and draw business strategies against unforeseen impacts. Moreover, these actions would continue long after the event, take root, and yield fruit.

Japan has recovered from diverse catastrophes, yet even with our experience and acquired wisdom we know more is needed. Other countries, from Australia through France and Greece to the US, have also suffered catastrophe, and our people are becoming concerned. To be up to the task, we must all learn from each other to reinforce our systems, particularly in rather new and vulnerable areas such as cybersecurity, digitalisation and of course climate change. Resilience, like the cherry tree at the OECD, needs to take deeper and wider root in Japan and in other countries too, to help us all not only to survive major tests, but to flourish in our daily lives as well.

COECD Observer, November 2018

\section{References}

https://one.oecd.org/document/SG/NAEC(2018)5/en/pdf https://one.oecd.org/ document/SG/NAEC(2018)5/en/pdf

http://oecdobserver.org/news/fullstory.php/aid/4550/ http://oecdobserver.org/ news/fullstory.php/aid/4550/

http://oecdtohokuschool.sub.jp http://oecdtohokuschool.sub.jp 